\title{
MIR7-1 Gene
}

National Cancer Institute

\section{Source}

National Cancer Institute. MIR7-1 Gene. NCI Thesaurus. Code C80711.

This gene is involved in the regulation of gene expression and plays a role in the development of carcinomas of the lung and breast. 